\title{
PENGARUH KUALITAS PELAYANAN TERHADAP KEPUASAN PELANGGAN DALAM MENGGUNAKAN LAYANAN OJEK ONLINE DI KARAWANG
}

\author{
Lania Muharsih \\ Email: lania.muharsih@ubpkarawang.ac.id
}

\section{Fakultas Psikologi, Universitas Buana Perjuangan Karawang}

\begin{abstract}
The progress of this online transportation company certainly depends on the quality of service provided to its customers. Companies engaged in online-based transportation service providers are required to provide good service to their customers in order to satisfy their customers. This study aims to determine the effect of service quality on customer satisfaction in using online taxibike services in Karawang. The research method used is quantitative research methods with non-experimental research design. Sampling in this study was carried out by using a quota sampling technique. The number of samples in this study were 384 respondents. The method of data collection was carried out using service quality instruments with 57 valid items and customer satisfaction instruments with 29 valid items. Based on the Cronbach Alpha formula, the reliability coefficient of the service quality instrument is 0.978 and the customer satisfaction instrument is 0.907 , which means that these two scales are very reliable. The results of the data analysis show that there is a positive effect of service quality on customer satisfaction in using online taxibike services in Karawang. This means that the better the quality of service provided by online taxibike service providers in Karawang, the higher customer satisfaction. The results of the calculation of the coefficient of determination show that service quality has a positive effect on customer satisfaction by $1.7 \%$, while the other $98.3 \%$ are influenced by other variables not examined in this study. The suggestions for further research are examining other variables that can affect customer satisfaction, such as service quality and price.
\end{abstract}

Keywords: Service quality, customer satisfaction, online taxibike

Abstrak. Kemajuan perusahaan transportasi online ini tentunya bergantung pada kualitas pelayanan yang diberikan untuk para pelanggannya. Perusahaan yang bergerak di bidang jasa penyedia transportasi berbasis online dituntut untuk memberikan pelayanan yang baik kepada pelanggannya agar bisa memuaskan pelanggannya. Penelitian ini bertujuan untuk mengetahui pengaruh kualitas pelayanan terhadap kepuasan pelanggan dalam menggunakan layanan ojek online di Karawang. Metode penelitian yang digunakan adalah metode penelitian kuantitatif dengan desain penelitian non-eksperimental. Pengambilan sampel pada penelitian ini dilakukan dengan teknik pengambilan sampel kuota. Adapun jumlah sampel dalam penelitian ini sebanyak 384 responden. Metode pengumpulan data dilakukan dengan menggunakan instrumen kualitas pelayanan sebanyak 57 item sahih dan instrumen kepuasan pelanggan sebanyak 29 item sahih. Berdasarkan rumus Alpha Cronbach diperoleh koefisien reliabilitas instrumen kualitas pelayanan sebesar 0,978 dan instrumen kepuasan pelanggan sebesar 0,907, yang berarti kedua skala ini sangat reliabel. Hasil analisis data menunjukkan bahwa terdapat pengaruh positif kualitas pelayanan terhadap kepuasan pelanggan dalam menggunakan layanan ojek online di Karawang. Artinya semakin baik kualitas pelayanan yang diberikan penyedia jasa layanan ojek online di Karawang maka semakin tinggi kepuasan pelanggan. Hasil perhitungan koefisien determinasi menunjukkan bahwa kualitas pelayanan memberikan pengaruh positif terhadap kepuasan pelanggan sebesar $1,7 \%$, sedangkan 98,3\% lainnya dipengaruhi oleh variabel-variabel lain yang tidak diteliti dalam penelitian ini. Adapun saran untuk penelitian selanjutnya yaitu meneliti variabel-variabel lain yang dapat memengaruhi kepuasan pelanggan misalnya kualitas jasa dan harga.

Kata Kunci: Kualitas pelayanan, kepuasan pelanggan, ojek online

\section{9 | Psychophedia Jurnal Psikologi Universitas Buana Perjuangan Karawang}




\section{Pengantar}

Perkembangan dunia bisnis saat ini mengalami pertumbuhan yang sangat pesat, baik bisnis yang bergerak di bidang jasa atau bidang non jasa. Perkembangan perekonomian secara menyeluruh yang diiringi dengan perkembangan teknologi dan ilmu pengetahuan menciptakan sebuah persaingan yang semakin ketat, baik di pasar domestik maupun pasar internasional. Oleh karena itu dalam persaingan yang demikian, perusahaan dituntut untuk dapat memuaskan pelanggannya dengan menciptakan produk atau jasa yang berkualitas sesuai dengan keinginan konsumen.

Kehidupan masyarakat saat ini lebih dinamis dibandingkan dengan era sebelum teknologi informasi berkembang pesat. Berbagai macam kesibukan yang dimiliki oleh masyarakat membuat seakan-akan masyarakat merasa kekurangan waktu untuk melakukan beberapa pekerjaan untuk memenuhi kebutuhan sehari-hari. Kesibukan yang paling dirasakan menyita waktu antara lain pengiriman paket dalam kota, pengantaran ke tempat tujuan yang biasanya terkendala macet dan angkutan umum, antri yang menyita waktu, dan belanja kebutuhan. Di kehidupan masyarakat, kita temui para pekerja yang berkesempatan untuk menawarkan jasa antar menggunakan motor yang dimiliki yang disebut tukang ojek. Tukang ojek tradisional hanya melayani jasa antar saja. Hal ini berpengaruh terhadap kurangnya pemenuhan kebutuhan masyarakat yang membutuhkan bantuan berupa jasa kurir, belanja, antar dan antri (Roesdijanto dkk, 2016).

Seiring dengan perkembangan zaman saat ini terdapat inovasi terbaru, yaitu transportasi berbasis transportasi online yang didukung oleh teknologi komunikasi melalui smartphone. Transportasi berbasis online ini merupakan penggabungan dari segi jasa transportasi ojek dan teknologi komunikasi. Selain jasa dan teknologi komunikasi, transportasi berbasis aplikasi online juga dilengkapi dengan fitur Global Positioning System atau yang lebih dikenal dengan GPS untuk memberikan informasi keberadaan pengemudi dan pengguna dengan rute terdekat. Di Indonesia sendiri ada beberapa perusahaan jasa transportasi online yang beroperasi antara lain Go-Jek dan Grab. Kelebihan yang dimiliki oleh jasa transportasi online adalah adanya fiturfitur yang sangat menarik dan bermanfaat untuk pelanggan contohnya adalah Grab Food dan Go Food. Hal ini sangat membantu bagi pelanggan yang sedang sibuk atau malas keluar untuk membeli makanan. Memberikan pelayanan terbaik untuk konsumen menjadi tolak ukur keberhasilan suatu perusahaan. Perusahaan yang berhasil memasarkan produk barang/jasanya kepada konsumen dengan pelayanan yang memuaskan mendapatkan brand yang baik di masyarakat. Pelayanan yang dimaksud termasuk pelayanan sewaktu menawarkan produk/jasa, pelayanan ketika memberikan jasa, pelayanan atas resiko yang terjadi saat memberikan jasa dan pelayanan lainnya.

Kualitas pelayanan menurut Kotler (dalam Roesdijanto dkk, 2016) adalah sebuah kinerja yang dapat ditawarkan oleh seseorang kepada orang lain. Kinerja ini dapat berupa tindakan yang tidak berwujud serta tidak berakibat pada kepemilikan barang apapun dan terhadap siapapun. Kualitas pelayanan yang baik akan memberikan dampak yang baik pula bagi perusahaan karena akan menjadi pelanggan yang loyal dan memberikan keuntungan bagi perusahaan (Roesdijanto dkk, 2016).

Menurut para akademisi, kepuasan pelanggan merupakan konstruk yang berdiri sendiri dan dipengaruhi oleh kualitas layanan (Oliver dalam Aryani dan Rosinta, 2010). Kualitas layanan juga dapat mempengaruhi loyalitas pelanggan secara langsung (Zeithaml dkk. dalam Aryani dan 
Rosinta, 2010) dan mempengaruhi loyalitas pelanggan secara tidak langsung melalui kepuasan (Caruana dalam Aryani dan Rosinta, 2010). Kualitas layanan mendorong pelanggan untuk komitmen kepada produk dan layanan suatu perusahaan sehingga berdampak kepada peningkatan market share suatu produk. Kualitas layanan sangat krusial dalam mempertahankan pelanggan dalam waktu yang lama. Perusahaan yang memiliki layanan yang superior akan dapat memaksimalkan performa keuangan perusahaan. Kualitas pelayanan yang baik akan berdampak pada kepuasan pelanggan selaku konsumen. Kepuasan pelanggan terhadap layanan dan hasil kinerja akan sangat mempengaruhi image perusahaan, sehingga hal ini menjadi perhatian penting bagi perusahaan (Gilbert dkk. dalam Aryani dan Rosinta, 2010).

Kepuasan pelanggan adalah tingkat perasaan seseorang setelah membandingkan kinerja atau hasil yang dirasakan dibandingkan dengan harapannya (Kotler \& Keller, 2016). Menurut Lovelock \& Wirtz (dalam Lubis \& Andayani, 2017) kepuasan adalah suatu sikap yang diputuskan berdasarkan pengalaman yang didapatkan. Kepuasan merupakan penilaian mengenai ciri atau keistimewaan produk atau jasa, yang menyediakan tingkat kesenangan konsumen berkaitan dengan pemenuhan kebutuhan konsumsi. Kepuasan konsumen dapat diciptakan melalui kualitas, pelayanan, dan nilai. Kunci untuk menghasikan kesetiaan pelanggan adalah memberikan nilai pelanggan yang tinggi (Lubis \& Andayani, 2017).

Karawang adalah salah satu kota industri terbesar di Indonesia. Sesuai dengan julukan kota industri, Karawang kini hadir dengan perusahaan-perusahaan yang berdiri di atas lahan penduduk dengan mayoritas penduduk berbahasa Sunda. Sebagai sebuah kota industri, masyarakat yang tinggal di kota Karawang memiliki pertumbuhan perekonomian yang semakin maju dengan perkembangan teknologi yang semakin berkembang. Kebutuhan akan kualitas pelayanan juga semakin meningkat karena penduduk kota Karawang adalah orang-orang yang mayoritas bekerja di pabrik, sehingga dengan kesibukan tersebut masyarakat cenderung menginginkan pelayanan yang baik. Dengan adanya ojek online, masyarakat yang berada di kota Karawang bisa memiliki berbagai pilihan mode transportasi untuk memenuhi kebutuhan bertransportasi sehari-hari. Dengan berbagai kemudahan yang bisa didapat dalam menggunakan transportasi ojek online, dibutuhkan kualitas pelayanan yang baik sehingga timbul kepuasan pelanggan dalam menggunakan fasilitas ojek online. Berdasarkan uraian tersebut peneliti ingin mengetahui pengaruh kualitas pelayanan terhadap kepuasan pelanggan dalam menggunakan layanan ojek online di Karawang. Tujuan penelitian ini adalah untuk mengetahui tingkat kualitas pelayanan ojek online di Karawang, tingkat kepuasan pelanggan dalam menggunakan layanan ojek online di Karawang, dan pengaruh kualitas pelayanan terhadap kepuasan pelanggan dalam menggunakan layanan ojek online di Karawang.

\section{Metode Penelitian}

Metode penelitian yang digunakan dalam penelitian ini adalah metode kuantitatif. Menurut Azwar (2018) metode penelitian kuantitatif adalah metode penelitian yang menekankan analisisnya pada data-data kuantitatif (angka) yang dikumpulkan melalui prosedur pengukuran dan diolah dengan metoda analisis statistika. Metode kuantitatif dapat diartikan sebagai metode penelitian yang berlandaskan pada filsafat positivisme, digunakan untuk meneliti pada populasi atau sampel tertentu, pengumpulan data menggunakan instrumen penelitian, 
analisis data bersifat kuantitatif/statistik, dengan tujuan menguji hipotesis yang telah ditetapkan (Sugiyono, 2017).

Jenis penelitian ini yaitu penelitian non-eksperimental. Penelitian noneksperimental adalah penelitian yang melakukan pengukuran pengaruh variabel bebas terhadap variabel terikat tanpa memberikan perlakuan-perlakuan khusus terhadap variabel terikat (Sugiyono, 2017).

Penelitian ini dilakukan di Karawang pada bulan Februari 2020 sampai dengan bulan Desember 2020. Populasi pada penelitian ini adalah pengguna layanan ojek online di Karawang dengan jumlah populasi tidak diketahui. Metode pengambilan sampel yang digunakan dalam penelitian ini adalah nonprobability sampling. Nonprobability sampling adalah teknik pengambilan sampel yang memberi peluang atau kesempatan yang sama bagi setiap unsur atau anggota populasi yang dipilih untuk menjadi sampel (Sugiyono, 2017). Teknik pengambilan sampel yang digunakan adalah teknik pengambilan sampel kuota yaitu teknik untuk menentukan sampel dari populasi yang mempunyai ciri-ciri tertentu sampai jumlah (kuota) yang diinginkan (Sugiyono, 2017). Adapun jumlah sampel dalam penelitian ini sebanyak 384 responden.

Pengambilan data dilakukan dengan menggunakan skala yang diisi langsung oleh subjek penelitian dan juga skala online yang dibagikan melalui aplikasi whatsapp.

Instrumen yang digunakan dalam pengumpulan data berupa skala Likert. Skala ini dirancang untuk mengungkap sikap pro dan kontra, positif dan negatif, atau setuju dan tidak setuju terhadap suatu objek sosial (Azwar, 2018). Skala sikap berisi objek sikap dan pernyataan sikap, serta terdiri atas dua macam, yaitu pernyataan yang mendukung atau memihak pada objek sikap (favorable) dan pernyataan yang tidak mendukung pada objek sikap (unfavorable). Penelitian ini menggunakan dua skala yaitu skala kualitas pelayanan dan skala kepuasan pelanggan.

Skala kualitas pelayanan terdiri dari 57 item sahih dan disusun berdasarkan dimensi-dimensi kualitas pelayanan menurut Lupiyoadi (2013), diantaranya yaitu tangibles (bukti langsung), reliability (kehandalan), responsiveness (daya tanggap), assurance (jaminan), dan emphaty (perhatian). Skala kepuasan pelanggan terdiri dari 29 item sahih dan disusun berdasarkan aspek-aspek kepuasan pelanggan menurut Gerson (2001), diantaranya yaitu harapan, kebutuhan, emosional, dan kinerja yang dirasakan pelanggan.

\section{Teknik Analisis Data}

Uji Normalitas

Pada penelitian ini peneliti menggunakan Kolmogorov Smirnov untuk menguji normalitas data. Perhitungan Kolmogorov Smirnov dilakukan dengan cara membandingkan nilai signifikansi Kolmogorov Smirnov hitung dengan taraf signifikansi 5\% atau > 0,05 (Sugiyono, 2017). Apabila nilai signifikansi Kolmogorov Smirnov hitung lebih besar atau sama dengan nilai 0,05 maka distribusi data dinyatakan normal dan apabila lebih kecil dari 0,05 maka dinyatakan tidak normal.

\section{Uji Linieritas}

Uji linieritas dilakukan untuk melihat linieritas hubungan antara variabel terikat dengan variabel bebas (Sugiyono, 2017). Apabila nilai signifikansi lebih besar atau sama dengan 0,05 maka data dianggap linier, jika signifikansi lebih kecil atau kurang dari 0,05 maka data dianggap tidak linier.

Uji Hipotesis

Pada penelitian terdapat satu variabel bebas $(\mathrm{X})$ dan satu variabel terikat (Y) sehingga peneliti menggunakan analisis 
regresi linier sederhana. Uji hipotesis dilakukan dengan cara membandingkan nilai signifikansi dengan nilai $\mathrm{p}<0,05$ atau membandingkan nilai $\mathrm{F}$ hitung dengan $\mathrm{F}$ tabel. Apabila nilai signifikansi hitung lebih besar dari 0,05 maka $\mathrm{H}_{0}$ diterima, sebaliknya apabila nilai signifikansi hitung lebih kecil dari 0,05 maka $\mathrm{H}_{0}$ ditolak.

Uji Koefisien Determinasi

Nilai dari koefisien determinasi menunjukkan besarnya pengaruh variabel independen $(\mathrm{X})$ terhadap variabel dependen (Y).

Uji Kategorisasi

\begin{abstract}
Peneliti melakukan kategorisasi di dalam penelitian ini berdasarkan ketegorisasi jenjang. Uji kategorisasi ditujukan untuk menempatkan individu ke dalam kelompok-kelompok yang posisinya berjenjang menurut suatu kontinum berdasar atribut yang diukur (Azwar, 2018).
\end{abstract}

\section{Hasil Penelitian Dan Pembahasan}

Sampel dalam penelitian ini berjumlah 384 responden, diantaranya 142 responden atau $36,98 \%$ berjenis kelamin laki-laki dan 242 responden atau 63,02\% berjenis kelamin perempuan. Adapun grafiknya dapat dilihat di bawah ini:

\section{Grafik 1 \\ Sampel Penelitian Berdasarkan Jenis Kelamin}

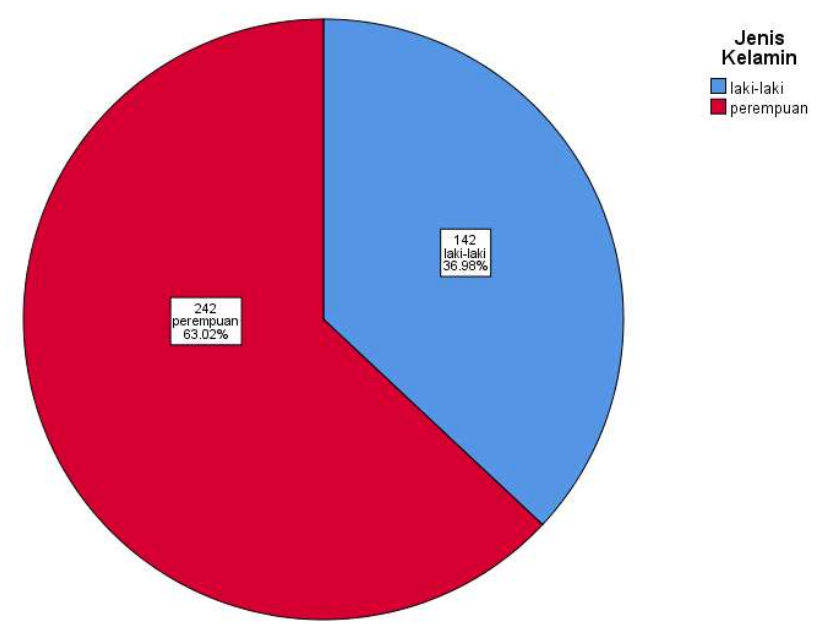

Jika dilihat berdasarkan usia, dari 384 responden, sebanyak 87 atau $22,66 \%$ responden berusia 15-20 tahun, 170 responden atau $44,27 \%$ berusia 21-25 tahun, 69 responden atau $17,97 \%$ berusia 26-30 tahun, 25 responden atau 6,51\% berusia 31-35 tahun, 19 responden atau
$4,95 \%$ berusia $36-40$ tahun, dan 14 responden atau $3,65 \%$ berusia lebih dari 40 tahun. Pada penelitian ini sampel penelitian terbesar berada pada rentang usia 21-25 tahun. Adapun grafiknya dapat dilihat di bawah ini: 
Grafik 2

Sampel Penelitian Berdasarkan Usia

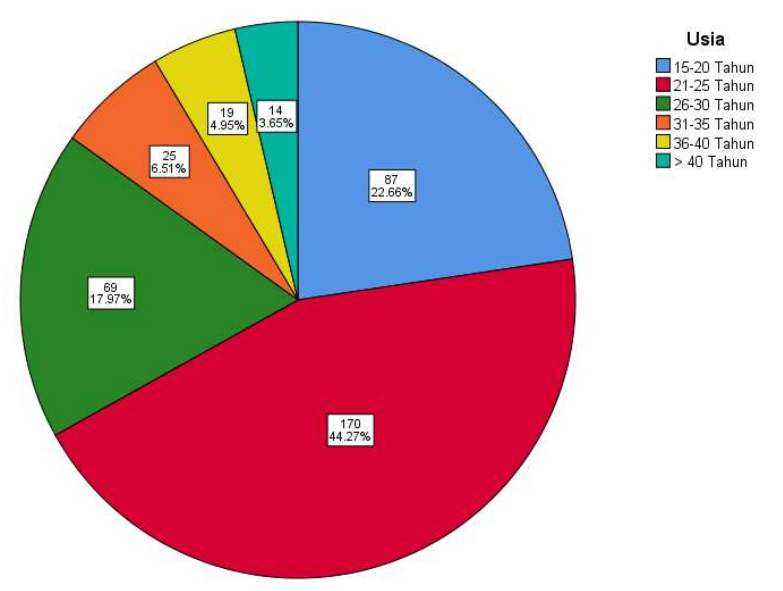

Responden penelitian berasal dari latar belakang pekerjaan yang berbeda, diantaranya 12 responden atau 3,13\% merupakan pegawai negeri, 158 responden atau $41,15 \%$ merupakan pegawai swasta, 32 responden atau $8,33 \%$ merupakan wiraswasta, 136 responden atau 35,42\% merupakan mahasiswa, dan 46 responden atau $11,98 \%$ dengan pekerjaan lainnya. Adapun grafiknya dapat dilihat di bawah ini:

\section{Grafik 3}

Sampel Penelitian Berdasarkan Pekerjaan

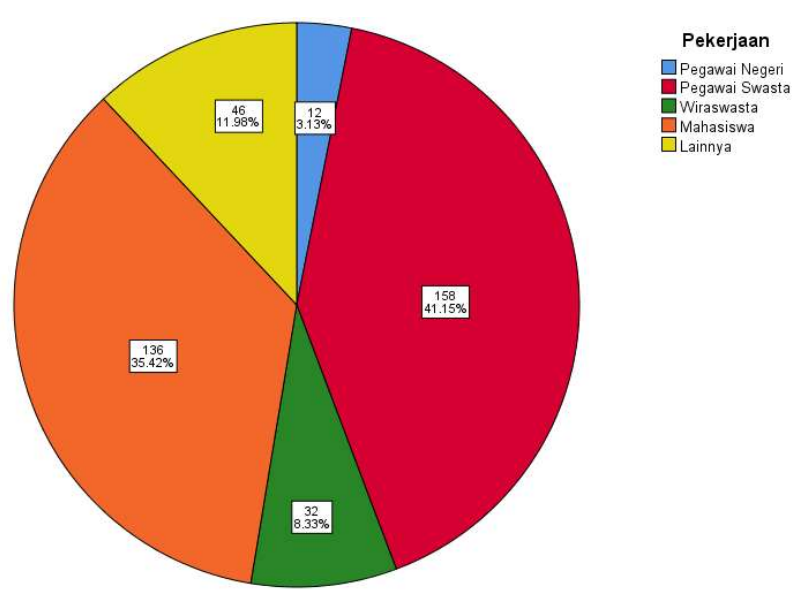

\section{Hasil Penelitian}

Uji Normalitas

Berdasarkan hasil uji normalitas didapat nilai signifikansi yang lebih kecil dari nilai $\alpha=0,05$ yaitu 0,000 untuk instrumen kualitas pelayanan dan nilai signifikansi yang lebih besar dari nilai $\alpha=0,05$ yaitu 0,061 untuk instrumen kepuasan pelanggan. Jadi dapat disimpulkan bahwa instrumen kualitas pelayanan berdistribusi tidak normal dan instrumen kepuasan pelanggan berdistribusi normal. 


\section{Uji Linieritas}

Hasil uji linieritas menunjukkan bahwa variabel kualitas pelayanan terhadap variabel kepuasan pelanggan memperoleh nilai Sig. Linearity sebesar $0,000<0,05$ yang berarti bahwa terdapat hubungan yang linier antara variabel kualitas pelayanan dengan variabel kepuasan pelanggan dalam menggunakan layanan ojek online di Karawang.

\section{Uji Hipotesis}

Hasil uji hipotesis menunjukkan bahwa nilai signifikansi yang diperoleh yaitu $0,010<0,05$ maka $\mathrm{H}_{\mathrm{o}}$ ditolak dan $\mathrm{H}_{\mathrm{a}}$ diterima sehingga terdapat pengaruh kualitas pelayanan terhadap kepuasan pelanggan dalam menggunakan layanan ojek online di Karawang.

Uji Koefisien Determinasi
Hasil uji koefisien determinasi menunjukkan angka $\mathrm{R}$ square $\left(R^{2}\right)$ sebesar 0,017 yang artinya pengaruh kualitas pelayanan terhadap kepuasan pelanggan dalam menggunakan layanan ojek online di Karawang adalah sebesar $1,7 \%\left(R^{2}=0,017\right)$ sedangkan 98,3\% lainnya dipengaruhi oleh variabel-variabel lain.

Uji Kategorisasi

Tingkat Kualitas Pelayanan Ojek Online Berdasarkan hasil uji kategorisasi dari 384 responden sebanyak 203 responden atau $52,9 \%$ memiliki tingkat kualitas pelayanan pada kategori baik, 163 responden atau 42,4\% memiliki tingkat kualitas pelayanan pada kategori cukup baik, dan 18 responden atau 4,7\% memiliki tingkat kualitas pelayanan pada kategori kurang baik. Berikut merupakan grafik tingkat kualitas pelayanan ojek online di Karawang:

\section{Grafik 4}

Tingkat Kualitas Pelayanan Ojek Online

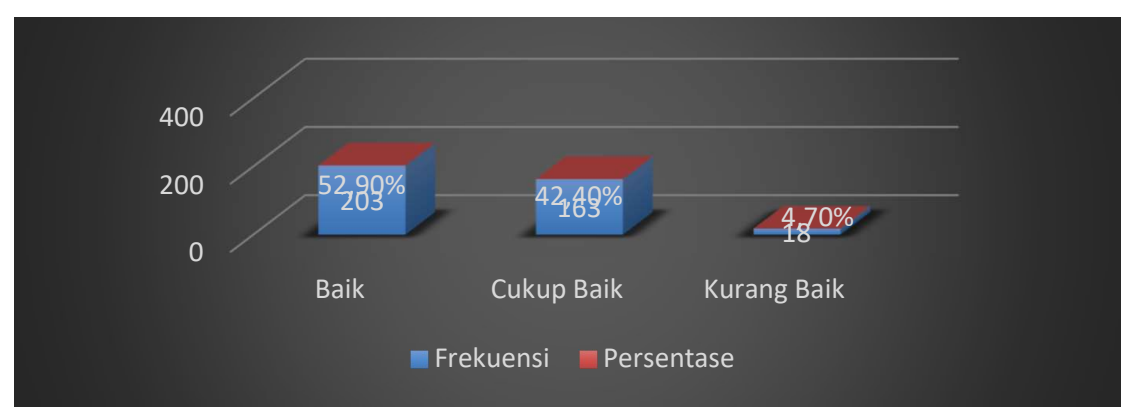

Tingkat Kepuasan Pelanggan

Berdasarkan hasil uji kategorisasi dari 384 responden sebanyak 166 responden atau 43,2\% memiliki tingkat kepuasan pelanggan pada kategori tinggi, 212 responden atau 55,2\% memiliki tingkat kepuasan pelanggan pada kategori sedang, dan 6 responden atau $1,6 \%$ memiliki tingkat kepuasan pelanggan pada kategori rendah. Berikut merupakan grafik tingkat kepuasan pelanggan dalam menggunakan layanan ojek online di Karawang: 
Grafik 5

Tingkat Kepuasan Pelanggan

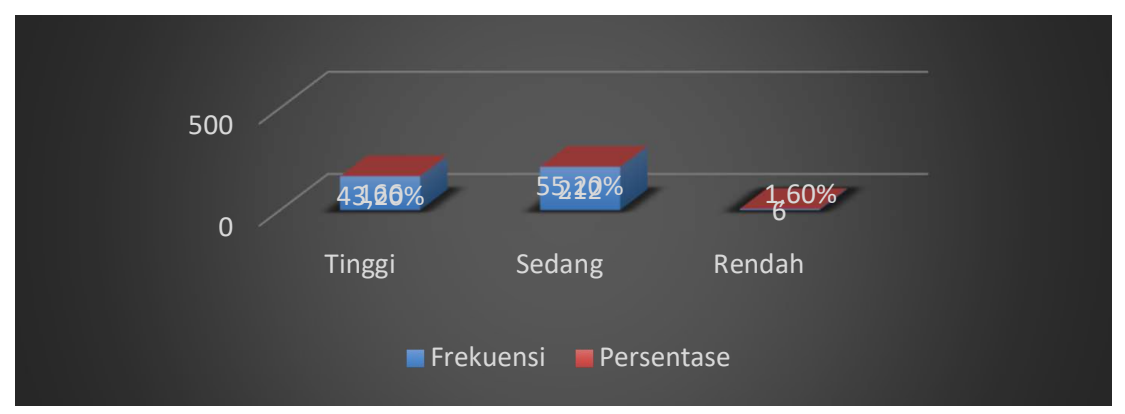

\section{Pembahasan}

Tingkat Kualitas Pelayanan Ojek Online

Sebagian besar responden menilai kualitas pelayanan yang diberikan ojek online di Karawang sudah baik dalam lima dimensi, yaitu bukti langsung (tangibles), kehandalan (reliability), daya tanggap (responsiveness), jaminan (assurance), dan perhatian (empathy). Bukti langsung merupakan kemampuan suatu perusahaan dalam menunjukkan eksistensinya kepada pihak eksternal. Sarana dan prasarana fisik perusahaan dan keadaan lingkungan sekitarnya adalah bukti nyata dari pelayanan yang diberikan oleh pemberi jasa, meliputi fasilitas fisik, perlengkapan, dan peralatan yang digunakan. Berdasarkan hal ini, responden atau pengguna layanan ojek online memiliki evaluasi yang baik terhadap fasilitas fisik, perlengkapan, dan peralatan yang digunakan oleh penyedia layanan.

Dimensi selanjutnya yaitu kehandalan (reliability) yang merupakan kemampuan perusahaan untuk memberikan pelayanan sesuai dengan yang dijanjikan secara akurat dan terpercaya. Sebagian besar responden menilai kinerja yang diberikan oleh penyedia layanan ojek online sudah sesuai dengan harapan pengguna, salah satunya dalam hal ketepatan waktu.

Selain itu, daya tanggap (responsiveness) yang merupakan kemauan untuk membantu dan memberikan pelayanan yang cepat (responsif) dan tepat kepada pelanggan dengan penyampaian informasi yang jelas juga dinilai baik oleh responden. Hal ini berarti penyedia layanan ojek online telah memberikan pelayanan yang cepat dan tepat kepada pelanggan.

Terkait dengan dimensi jaminan (assurance) yang merupakan pengetahuan, kesopan-santunan, dan kemampuan para driver untuk menumbuhkan rasa percaya para pelanggan juga sudah dinilai baik oleh responden. Dimensi lainnya yaitu perhatian (empathy) yang merupakan pemberian perhatian yang tulus dan bersifat individual atau pribadi yang diberikan kepada para pelanggan dengan berupaya memahami keinginan mereka. Sebagian besar responden merasa penyedia layanan ojek online telah memahami dengan baik kebutuhan pelanggan secara spesifik serta telah memberikan rasa nyaman bagi para pelanggan.

\section{Tingkat Kepuasan Pelanggan}

Sebagian besar responden cukup puas dengan layanan ojek online yang digunakan berdasarkan aspek-aspek harapan, kebutuhan, emosional, dan kinerja. Pada aspek harapan yang merupakan perkiraan atau keyakinan pelanggan tentang apa yang diterima bila menggunakan atau mengkonsumsi suatu barang atau jasa. Responden cukup yakin ketika 
menggunakan jasa ojek online sehingga mereka akan terus menggunakan layanan ini.

Aspek selanjutnya yaitu kebutuhan yang merupakan keinginan dari pelanggan terhadap perusahaan (barang atau jasa) sehubungan dengan pelayanan yang diberikan. Ketika membutuhkan layanan ini, sebagian besar responden akan menggunakan layanan jasa ini karena mereka telah memiliki keyakinan akan pelayanan yang diberikan.

Pada aspek emosional yang merupakan kondisi perasaan dan respon pelanggan sehubungan dengan kepuasan pelanggan yang ia terima, para responden cukup memiliki perasaan yang positif ketika menggunakan layanan ojek online. Selain itu, pada aspek kinerja yang dirasakan yang merupakan pandangan pelanggan mengenai pelayanan yang ia terima, responden cukup puas dengan pelayanan yang diterima.

Pengaruh Kualitas Pelayanan terhadap Kepuasan Pelanggan dalam Menggunakan Layanan Ojek Online di Karawang

Berdasarkan hasil uji hipotesis dengan menggunakan analisis regresi linier sederhana diketahui bahwa $\mathrm{H}_{0}$ ditolak dan $\mathrm{H}_{\mathrm{a}}$ diterima, artinya terdapat pengaruh kualitas pelayanan terhadap kepuasan pelanggan dalam menggunakan layanan ojek online di Karawang. Penyedia jasa layanan ojek online telah memberikan pelayanan yang baik atau sesuai dengan harapan pelanggan sehingga terwujud kepuasan pada para pelanggan. Kotler dan Keller (2016) menyebutkan bahwa kepuasan timbul karena kinerja sesuai dengan ekspektasi pelanggan. Kualitas pelayanan berpengaruh secara positif dengan kepuasan pelanggan. Hal ini menunjukkan semakin baik kualitas pelayanan yang diberikan oleh penyedia jasa layanan ojek online maka akan mampu meningkatkan kepuasan pelanggan. Kualitas pelayanan tersebut dapat dilakukan dengan memberikan pelayanan terbaik yang meliputi dimensi tangibles, reliability, responsiveness, assurance, dan empathy.

Selain itu, menurut Lau dan Lee (dalam Tjiptono \& Chandra, 2016) salah satu faktor yang memengaruhi kepuasan pelanggan adalah kualitas pelayanan. Konsumen atau pelanggan akan merasa puas apabila mereka mendapatkan pelayanan sesuai yang diharapkan. Jadi kepuasan pelanggan, dalam hal ini pengguna layanan ojek online, salah satunya dipengaruhi oleh kualitas pelayanan, dimana pengguna layanan ojek online di Karawang telah mengevaluasi kualitas pelayanan yang diterima dengan baik.

Hasil analisis data menunjukkan kualitas pelayanan memberikan pengaruh positif terhadap kepuasan pelanggan sebesar $1,7 \%$ sedangkan $98,3 \%$ lainnya dipengaruhi oleh faktor-faktor atau variabel-variabel lain yang tidak diteliti dalam penelitian ini. Artinya kualitas pelayanan yang diberikan penyedia jasa layanan ojek online berpengaruh positif terhadap kepuasan pelanggan. Semakin baik kualitas pelayanan maka semakin tinggi kepuasan pelanggan.

\section{Kesimpulan}

Berdasarkan hasil penelitian yang penulis lakukan mengenai pengaruh kualitas pelayanan terhadap kepuasan pelanggan dalam menggunakan layanan ojek online di Karawang, maka penulis menarik kesimpulan sebagai berikut:

1. Sebanyak $52,9 \%$ responden memiliki tingkat kualitas pelayanan pada kategori baik, 42,4\% memiliki tingkat kualitas pelayanan pada kategori cukup baik, dan 18 responden atau $4,7 \%$ memiliki 
tingkat kualitas pelayanan pada kategori kurang baik. Hal ini berarti sebagian besar responden menilai kualitas pelayanan yang diberikan penyedia jasa layanan ojek online di Karawang sudah baik

2. Sebanyak $55,2 \%$ responden memiliki tingkat kepuasan pelanggan pada kategori sedang, 43,2\% memiliki tingkat kepuasan pelanggan pada kategori tinggi, dan 1,6\% memiliki tingkat kepuasan pelanggan pada kategori rendah. Hal ini berarti sebagian besar responden cukup puas dalam menggunakan layanan ojek online di Karawang.

3. Terdapat pengaruh positif kualitas

\section{Kepustakaan}

Aryani, Dwi dan Rosinta, Febrina. (2010). Pengaruh kualitas layanan terhadap kepuasan pelanggan dalam membentuk loyalitas pelanggan. Jurnal Ilmu Administrasi dan Organisasi, 17(2)

Azwar, S. (2018). Metode penelitian psikologi. Yogyakarta: Pustaka Pelajar.

Kotler, P. (2008). Manajemen pemasaran di Indonesia (Analisis, Perencanaan, Implementasi, dan Pengendalian).

Kotler, Philip dan Armstrong. (2009).

Dasar-dasar pemasaran. Jakarta: PT Indeks.

Kotler, Philip dan Keller, K. L. (2016). Manajemen pemasaran. Jakarta: Erlangga.

Lubis, A. S., \& Andayani, N. R. (2017). Pengaruh kualitas pelayanan (service quality) terhadap kepuasan pelanggan PT Sucofindo Batam. pelayanan terhadap kepuasan pelanggan dalam menggunakan layanan ojek online di Karawang. Artinya semakin baik kualitas pelayanan yang diberikan penyedia jasa layanan ojek online di Karawang maka semakin tinggi kepuasan pelanggan. Hasil perhitungan koefisien determinasi menunjukkan bahwa kualitas pelayanan memberikan pengaruh positif terhadap kepuasan pelanggan sebesar $1,7 \%$, sedangkan $98,3 \%$ lainnya dipengaruhi oleh faktor-faktor atau variabel-variabel lain yang tidak diteliti dalam penelitian ini.

Journal of Business Administration, 1(2)

Lupiyoadi, Rambat. (2013). Manajemen Pemasaran Jasa. Jakarta: Salemba Empat.

Mowen, J. C., \& Minor, M. (2012). Perilaku konsumen. Jakarta: Erlangga.

Roesdijanto, dkk. (2016). Transformasi ojek tradisional ke ojek online. Jurnal Studi Manajemen dan Bisnis, 3(1).

Siregar, S. (2014). Metode penelitian kuantitatif. Jakarta: Kencana.

Sudaryono. (2017). Metodologi penelitian. Jakarta: Rajawali Pers.

Sugiyono. (2017). Metode penelitian kuantitatif, kualitatif dan $R \& D$. Bandung: CV Alfabeta.

Tjiptono, F. (2015). Strategi pemasaran. Yogyakarta: Penerbit Andi. 